\title{
Analysis of the difference in depths and variation in slope steepness of the Sunda Trench, Indonesia, east Indian Ocean
}

\author{
Polina LEMENKOVA ${ }^{1^{*}}$
}

${ }^{1}$ Schmidt Institute of Physics of the Earth, Russian Academy of Sciences, Department of Natural Disasters, Anthropogenic Hazards and Seismicity of the Earth, Laboratory of Regional Geophysics and Natural Disasters (Nr. 303). Bolshaya Gruzinskaya Str. 10, Bld. 1, 123995, Moscow, Russian Federation

Received 19 July 2020; Revised 19 November 2020; Accepted 23 November 2020

*Correspondence to: Polina LEMENKOVA, e-mail: pauline.lemenkova@gmail.com

\section{ABSTRACT}

The presented paper aims to assess the geomorphology of the Sunda Trench using the scripting cartographic techniques of Generic Mapping Tools (GMT). The GMT presents one of the technical mapping alternatives to the traditional GIS with well-defined scripting approaches for geomorphological mapping and scripting functionality which enables automatization in the geomorphological studies. In this context, modelling of the geospatial datasets is processing using machine learning approaches of GMT which presents fast and accurate modelling of the unreachable regions of the Earth, the deep-sea trenches. In this case, the study focused on the analysis of the submarine geomorphology of the selected segments of the Sunda Trench, located in the Indonesian archipelago, east Indian Ocean, by GMT scripting environment. This research effort is situated in the context of the geomorphology of the Sunda Trench. The aim is to point out which differences can be identified in the slope steepness of the cross-sectional profiles in the selected geomorphological segments of the trench in its southern and northern parts, as distinct by their geological settings and geospatial location. The actuality of the present paper is the analysis of the variations of the geomorphology in Indonesia supported by the GMT-based automated, machine-based geomorphological mapping, which plays an essential role in understanding of the Earth surface processes, supports managements of natural resources, provides information for monitoring and prognosis of natural hazards and enables to predict possible changes in geomorphological evolution of the landforms.

KEYWORDS submarine geomorphology; GMT; Sunda Trench; Indian Ocean; geology; cartography; mapping

\section{Introduction}

Various methods of geomorphological analysis have been discussed and described so far. To mention a few of them, these include geodetic measurements (Tregoning et al., 1994), aerial photo-interpretation and terrain analysis (Van Zuidam, 1985) GIS-based applications (Gauger et al., 2007; Bishop et al., 2012; 
Pubellier et al., 2003), modelling slopes and trends of the trenches (Lemenkova, 2019f, g). By far the most effective use of cartographic approaches for geomorphological studies is for the cross-section profiling as demonstrating 2D transects of the study area and depicting various geomorphic landforms and slope steepness.

Geomorphological mapping of the submarine features and seafloor is developing rapidly along with cartographic instruments and tools, and computer-based machine learning methods enabling effective data visualization, modelling and mapping. However, besides technical advances, marine geomorphology largely depends on using key progress in general geosciences (geology, environment, landscape studies, tectonics) deriving new data and information from different frontier disciplines of Earth sciences. Such a multidisciplinary approach is highly advantageous for our better understanding of various geomorphological processes recorded at the seafloor. It also results in using different approaches to the geomorphological assessment and various mapping criteria.

A novelty and major asset of the presented manuscript, which is being implemented using Generic Mapping Tools (GMT), is that it presents visualization of the submarine parts of the trench, provides methods of geomorphological modelling and applies quantitative measurements of the depths computations, which not only presents new data on the Indonesian archipelago, but also gives technical approaches that can be repeated in similar geomorphological studies, which has a significant asset due to the automatization of the used cartographic procedures. Hence, the originality of this paper consists in the presented models of the Sunda Trench using GMT, which has not been presented before in the existing literature. Moreover, the new visualized data on the submarine slopes of the Sunda Trench segments can be assimilated in other studies on Indonesian Archipelago and east Indian Ocean basin, as well as applied in the models based on other geospatial datasets (e.g., environmental, marine biological and other thematic studies).

A motivation for developing a present GMTbased geomorphological model of the Indonesian region was the need for automatization techniques in cartographic routines for the application of GMT modules using more sophisticated algorithms comparing to the traditional GIS. The automatization approach by GMT provides an effective means to visualize the seafloor in geomorphological mapping, an important surface between the geological substrate and the ocean mass where a range of phenomena (biochemical, hydrological, oceanological) are controlled by the geomorphological shape of the submarine landforms and geological character of the seafloor. Although maps of seafloor geomorphology are important for a wide range of science branches (geology, oil and gas engineering, fisheries and marine biological mapping), the cartographic techniques of the submarine geomorphological maps remain a challenge due to the remote location of the study object and the specifics of the GMT syntax. Besides, a submarine geomorphological mapping is strongly limited to the high-resolution data, that is a high-resolution GEBCO/SRTM topography grids.

In this context, work on the analysis and geomorphological modelling of bathymetric data in the Indonesian archipelago was stimulated by the availability of GEBCO dataset. In addition to used highresolution datasets (GEBCO, EGM-2008 etc), the GMT provides a cartographic methods of the geomorphological mapping through the significant level of the machine-based modelling and advanced solution for graphical visualization of the datasets. In the following parts of the paper a summary of the regional geological settings of the Indonesian archipelago is given, followed by a description of the GMT modelling of the topographic data, the algorithms used for cartographic visualization are discussed by giving the references to the methodology, and geospatial data retrieval through the available open source is described.

\section{Study area}

\subsection{Geographic location}

The study is focused on the Sunda Trench (also called Java Trench in the past), the deepest oceanic depression of the Indian Ocean, stretching 4,000$5,000 \mathrm{~km}$ parallel to the Sunda Island Arc, along its foot. Geographically, it stretches roughly in the NW- 
SE direction starting from the Andaman Islands, along the Indonesian archipelago, Sumatra, Java, and Lesser Sunda Islands until the Island of Timor. Its seafloor bottom has the irregular character being wider (up to $50 \mathrm{~km}$ ) in its northern part and gradually becoming narrow in the southern one (up to 10 $\mathrm{km})$. In particular, the paper analyses the difference in depths and variation in the slope steepness between the two segments of the trench: the southern Java transect (coordinates $108.8^{\circ} \mathrm{E} 10.10^{\circ} \mathrm{S}$ to $113.0^{\circ} \mathrm{E} 10.75^{\circ} \mathrm{S}$ ) and the northern Sumatra transect $\left(97.5^{\circ} \mathrm{E} 1.1^{\circ} \mathrm{S}\right.$ to $\left.101.0^{\circ} \mathrm{E} 5.5^{\circ} \mathrm{S}\right)$.

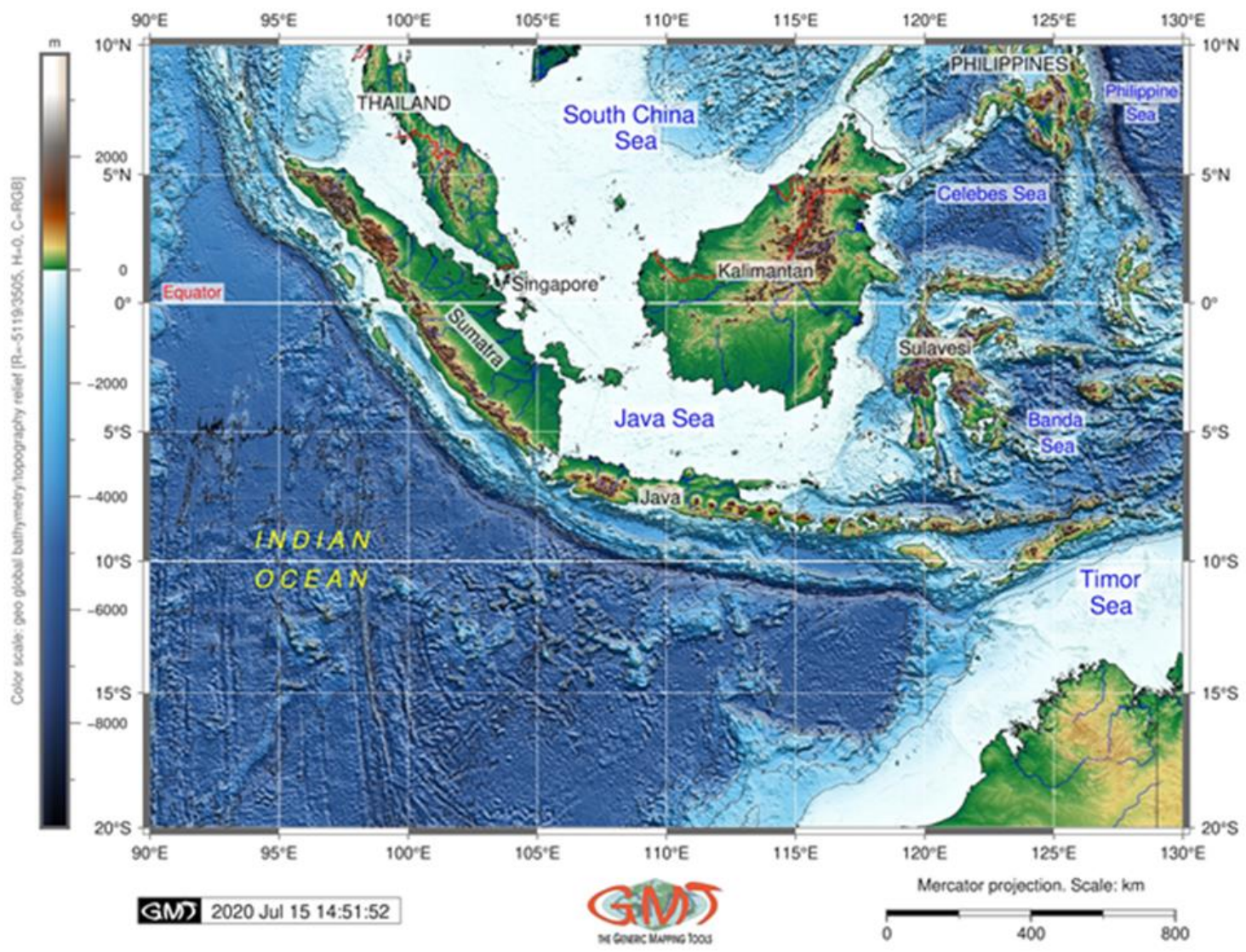

Figure 1 Topographic map of the West Indonesia region basin. GEBCO 15 arc sec resolution global terrain model grid

\subsection{Bathymetry}

The region of the Sunda Volcanic Arc includes the islands of Sumatra and Java, the Sunda Strait between them and the Lesser Sunda Islands stretching between 5 and $10^{\circ} \mathrm{S}$ (Rahardjo et al., 1995), Fig. 1. The depths of the seafloor in the Sunda Trench increase from the northwest $(-3,000 \mathrm{~m})$ to the southeast $(-6,000 \mathrm{~m})$, and reach its maximum at $-7,209 \mathrm{~m}$. Further to the east, the short Timor Trough $(-3,310$ $\mathrm{m})$ continues the Sunda Trench marking the boundary between the Indo-Australian Plate and the Timor Plate (Katili, 1972). It is separated by a threshold from the Seram Trough at Kai Islands Arch ($3680 \mathrm{~m}$ ). The Sunda Island Arc has a complex topographic structure. The northwestern part of the arc is bordered by the Andaman Sea which has a wide shelf in the east (with depths less than $100 \mathrm{~m}$ ) and an oval basin in the west. The seafloor bottom of the basin is dissected into several local troughs by a series of the submeridional submarine uphills with depths exceeding $-4000 \mathrm{~m}$ in its western part.

\subsection{Geomorphology}

The geomorphology framework of the Sunda Trench is largely controlled by the subduction of the Australian plate underneath the Sunda micro-plate. The geological processes take place in basin of the Indian Ocean at different stages of its evolution and influence the nature of the submarine geomorphol- 
ogy and geometric shape of the trench. The geomorphology of the Sunda Trench involves the partitioning of the submarine relief of the terrain into conceptual spatial entities based upon morphological criteria, geological processes, rock composition and structure, as well as tectonic evolution of the plates reflected in surface features of the deep-sea trench, and topological relationships of landforms. The submarine geomorphology of the Sunda Trench presents its various landforms and processes in the deep-sea region of the Indonesian archipelago. A variety of local landforms within the trench reflect the action of the selected impact factors at various spatio-temporal scales. These include such factors as tectonic, geological and oceanological ones. The study of the submarine landforms and processes, which largely reflect the evolution of submarine landscapes, has both theoretical and practical values. For example, the seafloor around the oceanic trench includes accumulated renewable and nonrenewable resources (e.g. hydrocarbons, deep-sea minerals), which is a practical aim in geological studies. The environmental purpose of the submarine geomorphology consists in the study of habitats of marine species which is necessary for modelling ecosystems among others.

\subsection{Tectonics}

The Java-Sumatra region is notable for the complexity of the tectonic processes in the active convergent tectonic plate margin marked by the subduction of the Indo-Australian Plate under the Eurasian Plate. The complexity of the tectonic setting in the region is illustrated by the presence of three major plates: the Eurasian, the Indian and the Australian with the Australian Plate diving under the Sunda Plate forming a subduction zone. The Indonesian segment of the Eurasian plate has been divided into three minor- and micro-plates that include the following ones: the Sunda Plate, the Banda Sea Plate, the Molucca Plate and the Timor Plate. More details about the tectonic evolution on the region are discussed in the available publications (Barber, 1981; Barber and Crow, 2009; Hamilton, 1977, 1978, 1979; Grevemeyer and Tiwari, 2006). The movement of the Australian plate northwest relative to the Wadati-Benioff zone resulted in the for- mation of the Sunda Trench-arc system. Local basin depressions of the Indian Ocean formed in the eastern part of the Sunda Island Arc and east of New Guinea where the structures were oriented across the main tectonic plate movement and experienced local rotations. As a consequence, such tectonic processes controlling the evolution of the Indian Ocean give rise to the different geomorphic features as long as they pass through the different periods of the geologic evolution.

The region of Sunda Trench was formed during late Paleozoic (Late Permian) and early Mesozoic (Triassic) periods as a result of the amalgamation of the continental and arc fragments in Indochina, Thailand, Malaysia, and Sumatra (Advokaat et al. 2018). Based on the wide distribution of the Mesozoic marine deposits found on the Sunda Island Arc, there was a deep-sea basin existed between Australia and Indochina during the Jurassic period of Mesozoic. This basin was connected with the Pacific Ocean in the east, and with the Tethys Ocean in the west. The presence of this basin on the territory of modern Sunda Island Arc points at the disintegration of the Gondwana, which occurred at the next period of its geological development. As a result of the seafloor expansion, the oceanic plate subducted under the continental Indo-Australian and Eurasian plates on the eastern border of Tethys during Cretaceous. During Paleogene, the rift zone of Tethys Ocean reduced due to the northward movement of Australia. As a consequence, its seafloor also moved northward, being absorbed in the Wadati-Benioff zone under the system of Sunda Island Arc. The oceanic passage from the Indian Ocean to the Pacific Ocean northward off Australia still existed at the end of the Eocene, although much narrower. Hence, the Sunda Trench-arc system was formed as a result of these complex tectonic movements in course of the geological history of the Indian Ocean region.

\subsection{Geology}

The geological processes and phenomena that take place in the bathymetric basins at different stages of ocean evolution influence the nature of submarine geomorphology and geometric shape of the deepsea trenches. Tectonic plate subduction and uplift- 
ing driving mechanisms across the Indonesian region have acted remarkably during Cenozoic (Advokaat et al., 2018; Daly et al., 1991; Setijadji et al., 2008; Smyth et al., 2005). The most important, among the many geologic processes that generate and shape the geomorphology of the slopes of the Sunda Trench is plate subduction, which includes bending of the oceanic lithosphere (Karig et al., 1980). Other geological factors affecting the formation of the oceanic trenches include volcanism and sedimentation (Moore et al., 1982; Moore and Curray, 1980; Lemenkova, 2019a, 2018). As a result of the variety of factors, the submarine geomorphology of the Indonesian region was formed. Its geomorphological features include rift valleys, spreading ridges, local minor troughs and a Sunda Trench. The subduction of the plate starts many of kilometers off the trench axis, being caused by the buoyance of the tectonic slab and the elastic nature of the lithosphere (Caméron et al., 1980). The beginning of the plate bending is noted by the outer rise, a bathymetric high on the seaward side of the trench (facing the Indian Ocean, opposite from the Indonesia).

The crystalline basement surface of the Cenozoic structures on the Sunda island arc almost coincides with the modern bathymetry forming the two ridges: the main ridge and the outer ridge, separated by a longitudinal trough with depths of up to 2-4 $\mathrm{km}$. The outer ridge has a steep slope to the Sunda Trench where depths reach up to $-6,000 \mathrm{~m}$. The sedimentary cover on the steep slopes of the Sunda Island Arc is generally thin increasing only in local depressions. The thickness of the Cenozoic deposits exceeds $1 \mathrm{~km}$ on the seafloor of the Sunda Trench (van Bemmelen, 1970). The lower seafloor layer on the island arcs and submarine ridges, hills and elevations at the bottom of the basin is mainly presented by the granite and metamorphic rocks of the continental crust, especially for the large islands, formed as folded mountain structures. The structure of the rocks of the Sunda Trench-arc system points at Paleozoic schists and gneisses, other metamorphic rocks, granite intrusions and occasional turbidite accumulation in the seafloor of the trench (McDonald, 1977; Anikouchine and Ling, 1967).

\subsection{Seismicity}

The Sunda Trench is a seismically active part of the Pacific Ring of Fire. A large number of the catastrophic earthquakes are recorded in the Indonesian archipelago, which makes this region especially prone to hazards and risks of the high seismicity (Bellier et al., 1997; Gunawan et al., 2018, 2020; Jena et al., 2020a, b; Marchetti et al., 2020; Moya et al., 2020; NASA, 2018; Socquet et al., 2019; Song et al., 2020; Yulianto et al., 2020). The seismic belt around it connects the Alpide orogenic system and the circum-Pacific seismic belt. A large number of catastrophic earthquakes are recorded and reported in various publications (Abercrombie et al., 2001; Pollitz et al., 2006; Sørensen and Atakan, 2008). The hypocentres of the earthquake surfaces are located under the Sunda Trench and Sunda Island Arc (Nalbant et al., 2005) which ultimately affect the geomorphological shape of the seafloor (Nurwihastuti et al., 2014).

The hypocenters of intermediate earthquakes (focal depth at 60-300 km) and deep-focus earthquakes (focal depth $>300 \mathrm{~km}$ ) form a focal zone with varying inclination: depth of ca. $300 \mathrm{~km}$ is $35^{\circ}$, and depth $>300 \mathrm{~km}$ is up to $60^{\circ}$, which indicates the fracture of the subducted oceanic plate. The morphology and depth of the subducted plate are defined by the earthquake hypocenters that vary along the plate boundaries (Cardwell and Isacks, 1978). Thus, the crust under the Sunda island arc is up to $25 \mathrm{~km}$ thick. It is composed of a thin layer with seismic wave velocities of $3.9-4.7 \mathrm{~km} / \mathrm{s}$ and much more thick main layers with wave velocities of 5.15.7 and $6.6-7.2 \mathrm{~km} / \mathrm{s}$ typical for solid crustal rocks. Under the seafloor bottom of the Sunda Trench the crustal thickness decreases to $14 \mathrm{~km}$ with layers having seismic velocities of 4.1 and $7.2 \mathrm{~km} / \mathrm{s}$ (Litvin, 1987). More detailed studies on the seismicity and earthquakes in the Indonesian region and Sunda Trench area exist in the published literature (to mention a few, Curray et al., 1977; Harjono et al., 1991; Kieckhefer et al., 1980; Kopp, 2011; Lemenkova, 2020c; Fujii and Satake, 2006; Ammon et al., 2006). 


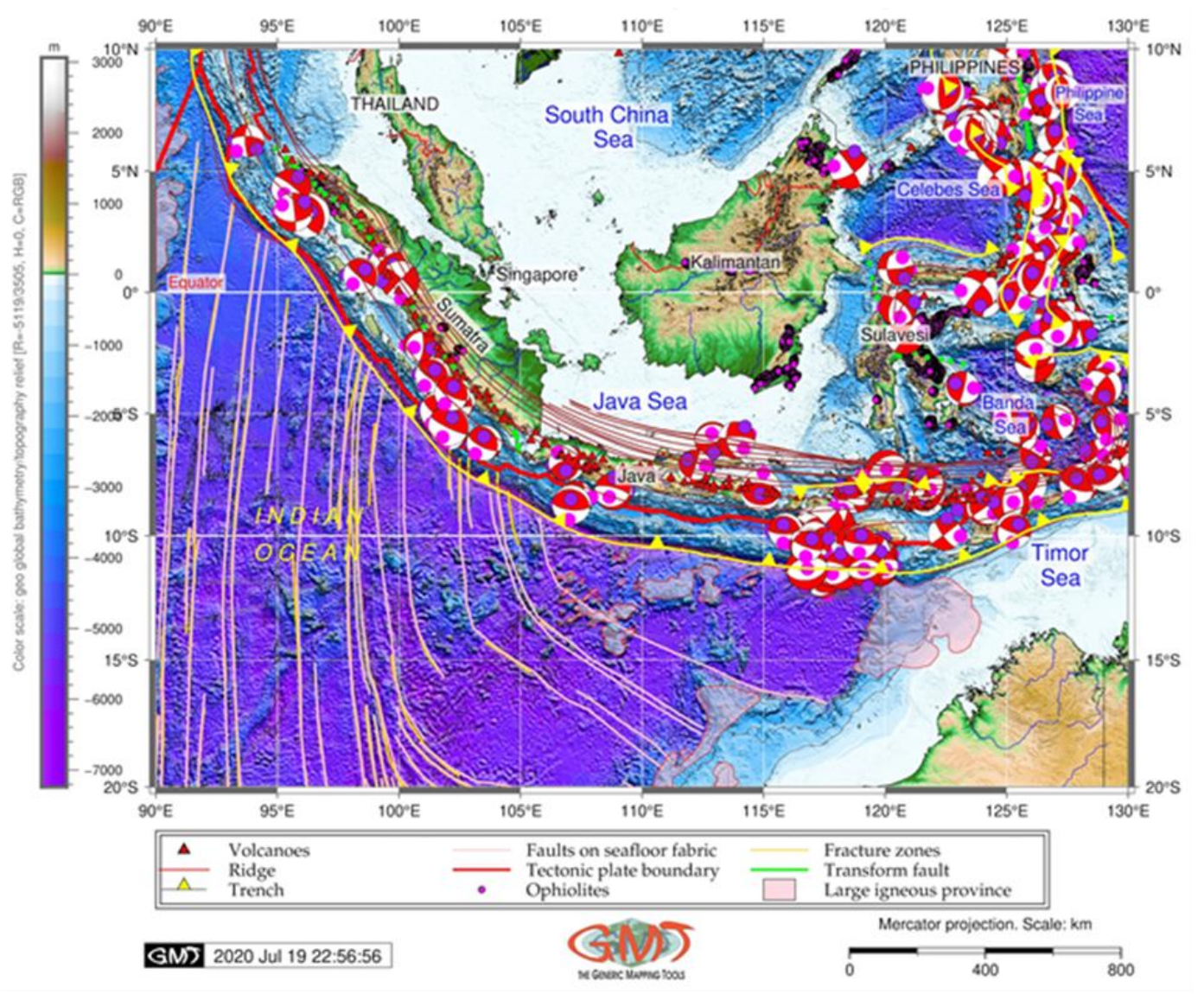

Figure 2 Geologic map of the West Indonesia basin. GEBCO 15 arc sec resolution global terrain model grid

\section{Material and Methods}

Numerical methods of the data processing are required to model the specifics and reconstruct the past Sumatra and Java tectonic movements. For instance, these include geodetic and paleogeodetic measurements (Chlieh et al., 2008), using GPS and InSAR measurements for estimating land subsidence (Abidin et al., 2008), resolution enhancement techniques for measuring discontinuity depth and correlation with the morphology of the subducting Indo-Australian slab (Dokht et al., 2018). Other approaches include, for example, reconstructed wave heights and ComMIT tsunami modelling (Meservy et al., 2020), method of the radiometric age determination of granitic rocks from the islands for analysis of the geological evolution and geochronology of west Indonesia based on the plate-tectonics concept (Katili, 1973). Development of cartographic methods is presented in works on marine mapping and visualization (Mammerickx et al., 1976), as well as automatization approaches in the GIS techniques
(Schenke and Lemenkova, 2008; Klinger et al., 2012; Lemenkova, 2019e).

The method used to perform cartographic visualization, modelling and mapping is based on the Generic Mapping Tools (GMT). The GMT is developed by Wessel and Smith (1991) and works as a scripting toolset of modules from a shell console. Since 1991 it has been used in geophysical and topographic mapping and being continuously developed since then (Wessel et al., 2013). The GMT has embedded vector shorelines and contours of major geographical objects (rivers, lakes, borderlands) for the World as a basis map used in this research (Wessel and Smith, 1996). For example, a group of modules (such as gmtset, gmtdefaults, grdcut, makecpt, grdimage, psscale, grdcontour, psbasemap, gmtlogo, psconvert and many others) was taken together to perform topographic mapping by a group of sub-tasks: subset raster grid from a raw file, to define projection, visualize, add cartographic elements, and convert the layout out- 
put to a graphical format. All this is done sequentially, in a GMT shell script consisting from a sequential line of codes, similar to the principle of programming.

Technical description of the procedure is as follows. First, a subset of the ETOPO1 raster grid has been extracted from the global GEBCO grid using the following code: "grdcut GEBCO_2019.nc R105/115/-14/-5.5 -Gstj_relief.nd". Then, the data have been checked up (extreme and range in meters) using GDAL library using the following code: "gdalinfo stj_relief.nc -stats". The data for the Java segment demonstrated the following data extent: Minimum=-7239 m, Maximum=3063 m. The data for the Sumatra segment demonstrated following data extent: Minimum=-7164 m, Maximum=3403 $\mathrm{m}$. The next step included making a color palette using the following code: "gmt makecpt -Cglobe -V $-T-7239 / 3063>$ myocean.cpt". Afterwards, the file was generated: "ps=crossSTJ.ps" and the raster image was visualized in the given geographic extent here example for the Java segment): "gmt grdimage stj_relief.nc -Cmyocean.cpt -R105/115/-14/-5.5 JM6i - P -I+a15+ne0.75-XC - K > \$ps".

The next two steps included adding a color scale by the following code: "gmt psscale Dg103.7/-14+w13c/0.4c+v+00.3/0i+m/

Rstj_relief.nc -J -Cmyocean.cpt -Baf+/"Colors for global bathymetry/topography relief $[R=-$ 7164/3403, $H=0, C=R G B]^{\prime \prime}-I 0.2-B y+/ m-O-K>>$ $\$ p s^{\prime \prime}$, and adding cartographic elements (grid, annotated coordinate projection and a time stamp) using the following GMT code: "gmt psbasemap $-R$ -J -Lx13.0c/-0.5i+c50+w250k+l"Mercator projection. Scale (km)"+f-Bpxg2f1a2 -Bpyg2f1a 1 -Bsxg 1 -Bsyg 1 $-B w E S N-U B L /-5 p /-35 p-O-K>>p s^{\prime \prime}$. The shorelines and plotted title were visualized using the following GMT code: "gmt grdcontour stj_relief.nc $-R$ $J$-C1000 - $B+t$ "Cross-sectional profiles of the Sunda Trench, Java segment. DEM: GEBCO" -WO.1p -O -K $>\$ p s^{\prime \prime}$.

After the cartographic work has been done, the topographic data were used to extract information on depths/heights and model the cross-section profiles. This was done using the following modelling procedure. First, the two points (start point and end point) were selected using UNIX 'cat' utility, as fol- lows: cat $<<$ EOF > trenchSTJ.txt 108.8 -10.10 113.0 -10.75 EOF (here EOF signifies "end of file" for the expression). Then the trench segment and end points were plotted (visualized on a map) using the following two chunks of code: 1) gmt psxy $-R-J-$ $W 2 p$, red trenchSTJ.txt $-O-K>>$ \$ps (plotting a line); 2) gmt psxy - $R$-J -ScO.15i -Gred trenchSTJ.txt $-O-K$ >> $\$ p s$ (plotting start and end points). Afterwards, a cross-track profiles were generated with the following parameters: $500 \mathrm{~km}$ long, sampled every $2 \mathrm{~km}$, spaced $10 \mathrm{~km}$ and stacked using the mean: "gmt grdtrack trenchSTJ.txt -Gstj_relief.nc C500k/2k/10k+v -Sm+sstackSTJ.txt > tableSTJ.txt, gmt psxy $-R-J-W 0.5 p$,yellow tableSTJ.txt $-O-K>>$ $\$ p s$ ". The data were written in a txt file: "gmt convert stackSTJ.txt -o0,6-I -T > > envSTJ.txt".

Finally, the graph has been plotted using the following code: Plot graph (statistical median for the profiles): "gmt psxy -R-250/250/-8500/1000 $J X 15.2 c / 5 c \quad-Y 15.5 c$ envSTJ.txt - W0.5p Bpxa50g100f10+l"Distance from trench $(\mathrm{km}) "$ Bpya1000gf500+l"Depth (m)" -Bsxg50 -Bsyg1000 Glightgray $-O-K>>p s^{\prime \prime}$. The median lines were added on the graphs using the code: "gmt psxy $-R$ $J-W 1.0 p-E y+p 0.2 p$ stackSTJ.txt $-O-K>>\$ p s, g m t$ psxy $-R-J-W 1.0 p$, red stackSTJ.txt $-O-K>>$ ps". Examples of other cartographic scripting are provided in the existing papers, for example GRASS GIS (e.g. Lemenkova, 2020a, 2020b). Comparing to GRASS GIS, a GMT approach is facilitated by a process division into sub-tasks and one or more modules 'responsible' for the executing these tasks that visualize certain cartographic elements (e.g. add annotations, coasts, visualize raster image from a grid, add colour legend, add information about projection, defile grid on the cartographic layout, etc.) and solutions by sketching them out on maps. To a certain extent, this principle can be compared to the structure of layers in a standard GIS menu, e.g. in the ArcGIS (Suetova et al., 2005; Lemenkova et al., 2012; Klaučo et al., 2014, 2017; Lemenkova, 2011). The result of a GMT data processing consists of the print-quality series of maps, geomorphological models, and descriptive statistical analysis.

The importance of the precision and accuracy of the raw topographic and geophysical data for mapping has been discussed previously (Smith, 1993; Wessel 
and Watts, 1988; Stagpoole et al., 2016; Weatherall et al., 2015). Therefore, high-resolution data were selected as the materials for this research: the topography based on the GEBCO 15-arc-second grid (GEBCO Compilation Group 2020) which is using SRTM basemap (Tozer et al., 2019), geoid based on the 2.5 minute Earth Gravitation Model of 2008 (EGM2008) raster grid (Pavlis et al., 2012), vector layers from the repository of Scripps Institution of Oceanography (SIO), U.S., marine free-air gravity grid (Sandwell et al., 2014; Smith and Sandwell, 1995), data on tectonic plate boundaries and

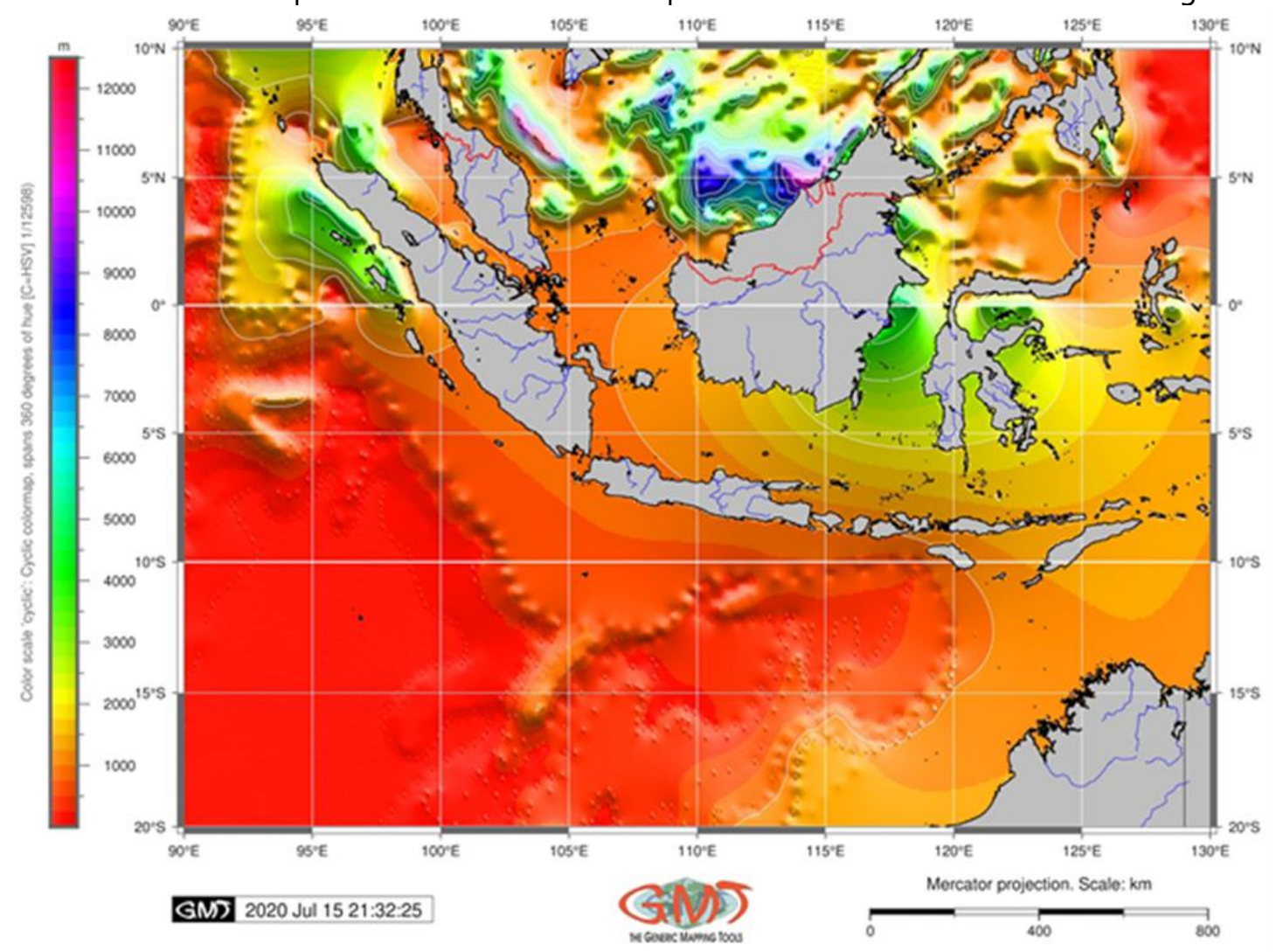

Figure 3 Sediment thickness of the West Indonesia basin. GlobSed 5 arc min grid V-3

\section{Results}

As a result of complex geological settings and tectonic evolution, the geomorphology of the Sunda Trench region is varying in its different segments. The outer slope of the Sunda Island Arc has a typical convex profile and stepped structure. The ridge of the Sunda Island Arc is formed here by massive submarine narrow elevations with stepped slopes. In general, the Sunda Island Arc is formed as a double arc stretching in a southeast direction to the New movements, geological data on earthquakes from the global CMT project (Ekström et al., 2012; Dziewonski et al., 1981). Sediment thickness data were taken from the GlobSed global 5-arc-minute total sediment thickness dataset (Straume et al., 2019). The information on the data layers, extend on topographic range (depths) and projections were retrieved using GDAL (GDAL/OGR contributors, 2020). The cross-section profiling was done using 'grdtrack' module of GMT by automated digitizing of the profile transects crossing the trench in a perpendicular direction in two selected segments. 
depressions, with depths gradually increasing from the NW $(-1000$ to $-1500 \mathrm{~m})$ to the SE $(-3700$ to -4000 $\mathrm{m})$. Some more detailed descriptions of the geo- morphology of the Sunda region supporting this study is given by Verstappen (2000), Curray et al. (1982) and Karig et al. (1979).

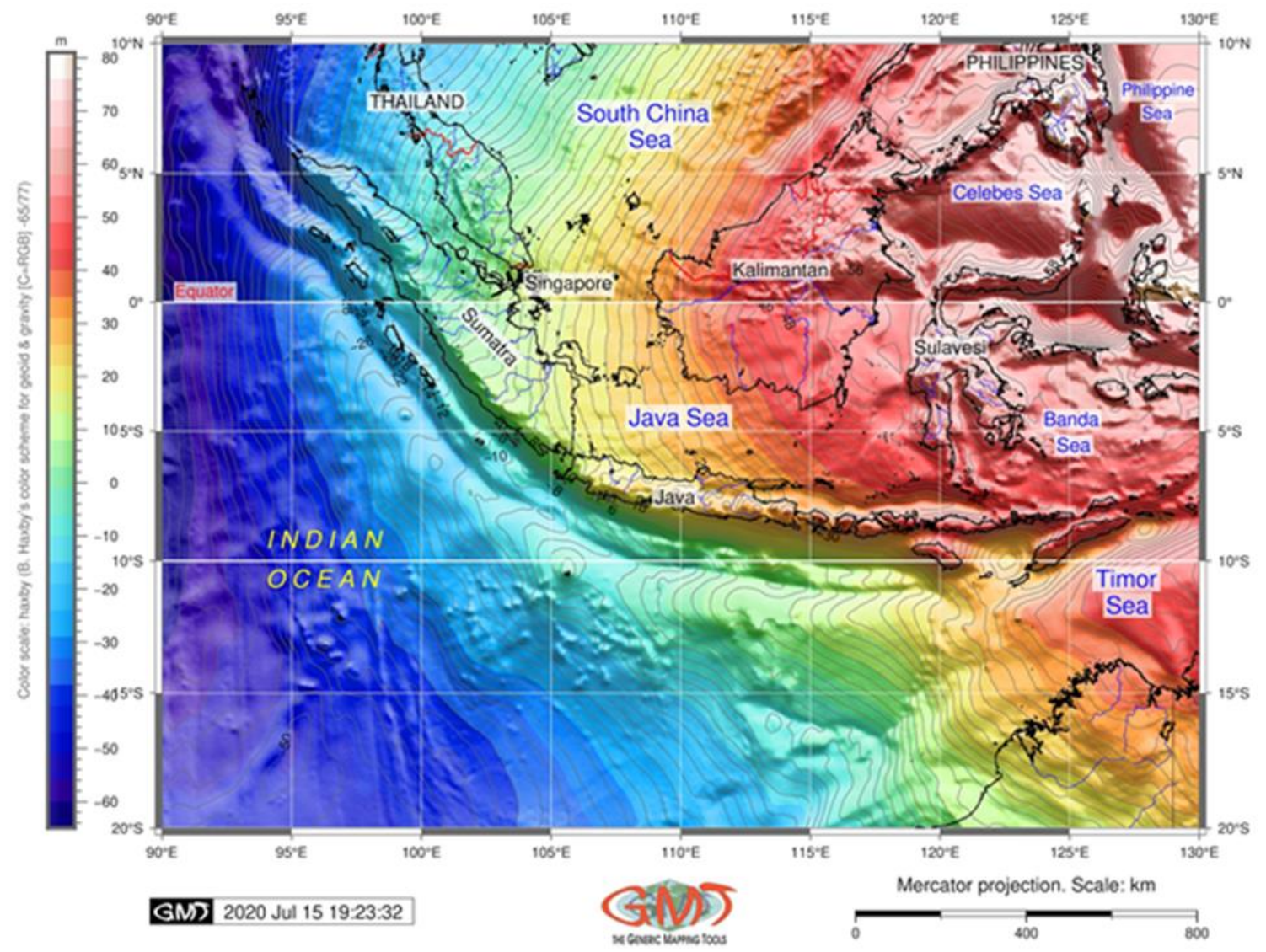

Figure 4 Geoid model of the West Indonesia basin. World geoid image EGM2008 vertical datum 2.5 min resolution

The seafloor bottom of the trench varies, being different in the segments off Sumatra and Java. In the southeast of Java, it is presented by a series of local depressions separated by the uphills. Comparing to other oceanic trenches, such as Tonga, Kermadec, Vityaz, Vanuatu, Kuril-Kamchatka (Lemenkova, 2019b, 2019c, 2020d), the slopes of the Sunda Trench are generally steeper and asymmetric. The asymmetry of the slopes is reflected in differential geometry of its oceanic and landward sides as follows: comparing to the oceanic slope, the landward slope is higher and steeper, more dissected by the canyons and complicated by the steps and ledges. In the Sumatra and northern Java segment, the seafloor bottom is up to $35 \mathrm{~km}$ wide, levelled by a layer of terrigenous sediments with a large ad- mixture of volcanic material, the thickness of which reaches up to $3 \mathrm{~km}$ in the north. The Sunda outer ridge stretches up to several hundred meters in heights, divided into two parts by a saddle along the Sunda Trench. Some block structures and separate seamounts rise with a height of 2,000-3,000 m rise on its convex surface.

The main topographic map of the region is based on the GEBCO grid (Fig. 1). The geologic data included several categories of objects related to the geologic settings of the Sunda Trench and Indonesia region: the location of trench and ridges, volcanoes, slabs, ophiolites, tectonic plate boundaries, focal mechanisms, showing the geological complexity of the region (Fig. 2). 


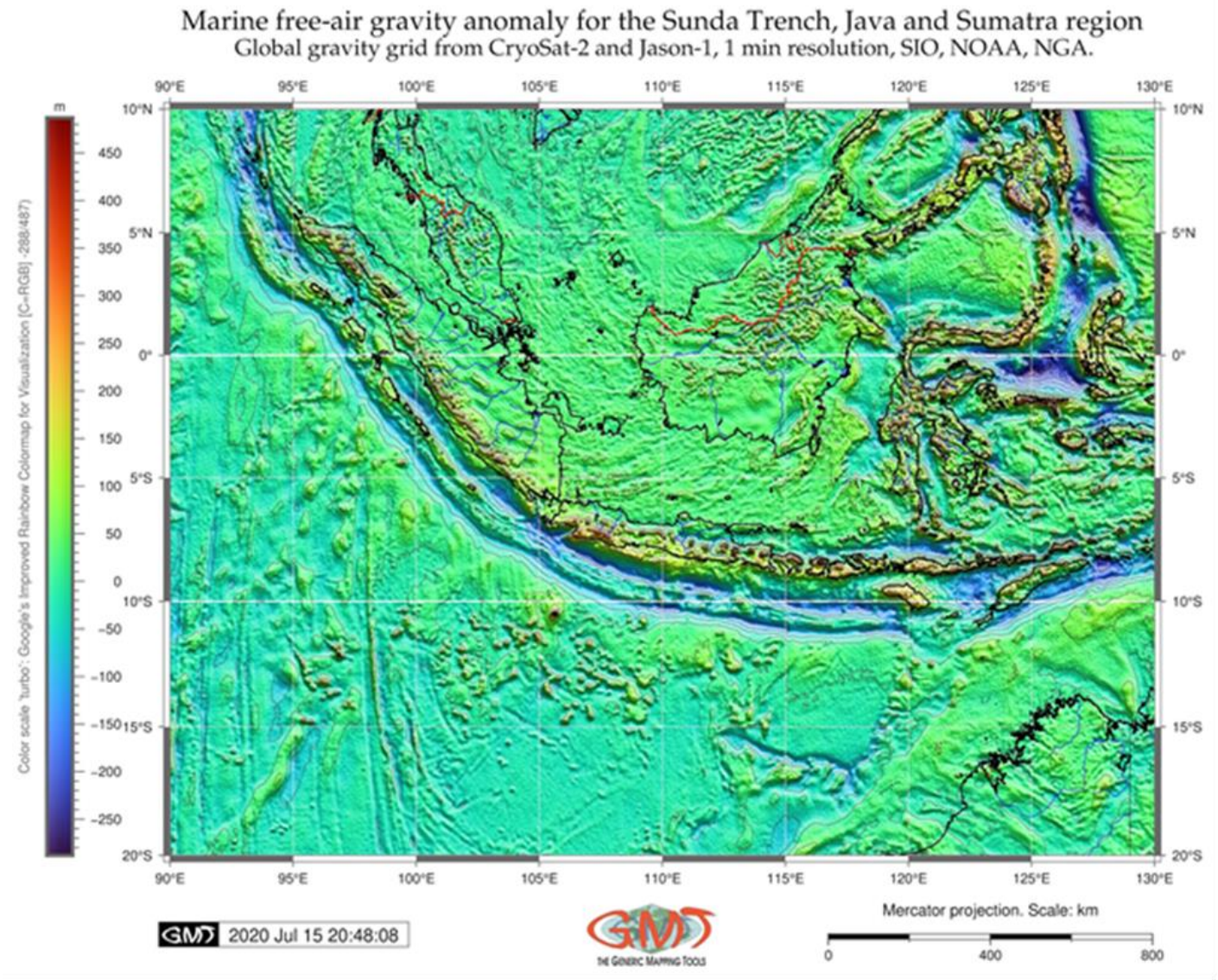

Figure 5 Marine free-air gravity map of the West Indonesia basin

The sediment thickness map depicts the thickness of the sediment layer with isolines plotted by each $1000 \mathrm{~m}$. The highest sediment thickness can be seen offshore the Kalimantan Island (blue, magenta to purple coloured areas Fig. 3) with values over $8,000 \mathrm{~m}$, with the highest values (magenta colour, $>10,000 \mathrm{~m}$ ) near the Brunei area, Brunei Bay (Fig. 3). The increased values of the sediment thickness can be seen to the south-east off Kalimantan, Sulawesi, north-west Sumatra (green to cyan colours in Fig. 3), values from 3,000 to $7,000 \mathrm{~m}$. That clearly points at the higher values of sediment in the Sumatra segment of the Sunda Trench comparing to the Java segment, where the dominating values are below 2,000 m (orange to red colours in Fig. 3).

The map of the geoid regional model (Fig. 4) clearly shows the asymmetric undulation over the study area: the higher categories of the geoid undulation with values above $45 \mathrm{~m}$ (red colours on Fig. 4) are seen in the north-eastern part of the map in the north-eastern region of the Indonesia Archipelago, the Celebes Sea and the Philippine Sea basin continuing over the terrestrial area of the Kalimantan and the Philippines. Comparing topographic contour (Fig. 1) with the geoid isolines (Fig. 4), one can see the correlation between the geophysical fields and topographic elevations. The area to the west of Kalimantan, Java, Sumatra and Thailand demonstrate a gradual decrease in the geoid values to $-10 \mathrm{~m}$ (light orange to green colours in Fig. 4). The regions of Sumatra and northern Thailand show negative values decreasing further to the region of the Indian Ocean with values below $45 \mathrm{~m}$ (blue to dark blue colours, Fig. 4). As for the region of the Sunda Trench, it shows slightly negative values of the -30 to $-10 \mathrm{~m}$ across the trench with a slight increase in its Java segment with 0 to $-5 \mathrm{~m}$ (light aquamarine colour) comparing to Sumatra segment, 5 to $-15 \mathrm{~m}$ (blueish to light cyan colour), Fig. 4. 


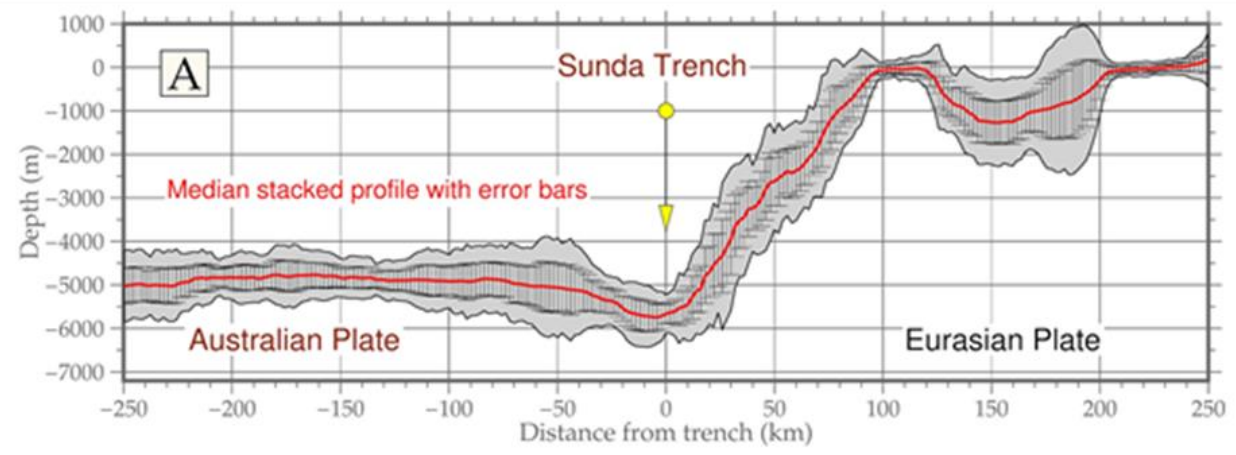

Cross-sectional profiles of the Sunda Trench, Sumatra segment. DEM: GEBCO

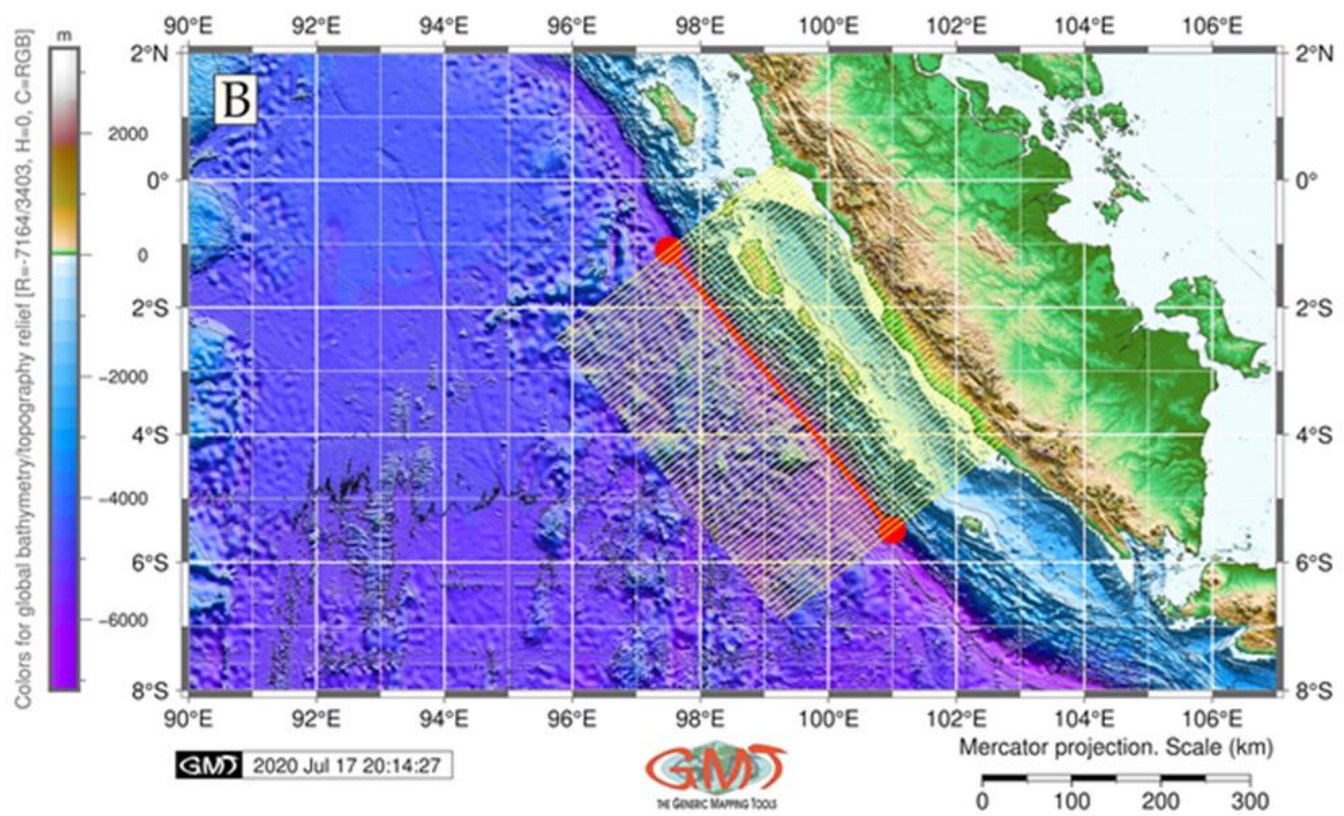

Figure 6 Cross-section profiles of the Sunda Trench: Sumatra segment

The dominating free-air gravity values are notable for the range of -40 to $40 \mathrm{mGal}$ (light aquamarine colour in Fig. 5). As for the regions of the Sunda Trench, it demonstrates lower values (-40 to -80 $\mathrm{mgGal}$ ) correlating with the physiographic isolines of the bathymetric map (Fig. 1) which points at the dependences between the distribution of the elevations and the geophysical anomaly fields. The highest values of the marine free-air gravity with $>200$ mGal (yellow to orange colours in Fig. 5) can be seen over the mountainous areas on Kalimantan and Indonesian archipelago, Sulawesi and central Thailand. The majority of the terrestrial area of Java and Sumatra indicate a correlation between gravity fields and topographic patterns of the mountains areas, Fig. 5.
The selected segments of the Sumatra and Java of the Sunda Trench are selected, since they are spatially distinguishable and formed under the impact of different local geological settings, which introduce a bias in the geomorphological shape of the Sunda Trench and thereby present various parts as more distinct segments. If two closely located segments were selected, the difference in the structure of the trench would have been eliminated and statistically less significant. Therefore, the two segments were selected as the most representative ones. Besides, the Sumatra segment extents in a clear north-west direction, while the Java segment stretches in the north-north-east direction. The comparison of these two segments of the Sunda Trench gives the following results: the Sumatra, which is the northern (Fig. 6) and the Java, which is 
the southern (Fig. 7) shows that Java segment has a more symmetrical shape form while the Sumatra segment has a clear asymmetric one-sided shape. The Sumatra segment of the Sunda Trench has a steepness of $57.86^{\circ}$ on its eastern side (facing Sumatra Island) and a contrasting $14.58^{\circ}$ on the western part facing the Indian Ocean (Fig. 6A). The digitized segment of the Sumatra transect has coordinates $97.5^{\circ} \mathrm{E} 1.1^{\circ} \mathrm{S}$ to $101.0^{\circ} \mathrm{E} 5.5^{\circ} \mathrm{S}$ (Fig. 6B). The Java segment of the Sunda Trench has a steepness of $64.34^{\circ}$ on its northern side (facing Java Island) and $24.95^{\circ}$ on the southern part facing the Indian Ocean (Fig. 7A). The digitized segment of Java transect has coordinates $108.8^{\circ} \mathrm{E} 10.10^{\circ} \mathrm{S}$ to $113.0^{\circ} \mathrm{E} 10.75^{\circ} \mathrm{S}$, (Fig. 7B). In both cases the cross-track profiles are plotted as cross-track profiles $500 \mathrm{~km}$ long $(250 \mathrm{~km}$ on each flank from the trench axis), sampled every 2 $\mathrm{km}$, spaced $10 \mathrm{~km}$ between each perpendicular line which can be seen in Fig. 6B and 7B as a set of thin, parallel yellow coloured lines. Despite the certain difference in a slope steepness of both flanks of the Java segment (Fig. 7), it has a more symmetric geometry form of the geomorphological profile comparing to the cross-section of the Sumatra segment (northern part of the Sunda Trench, Fig. 6).
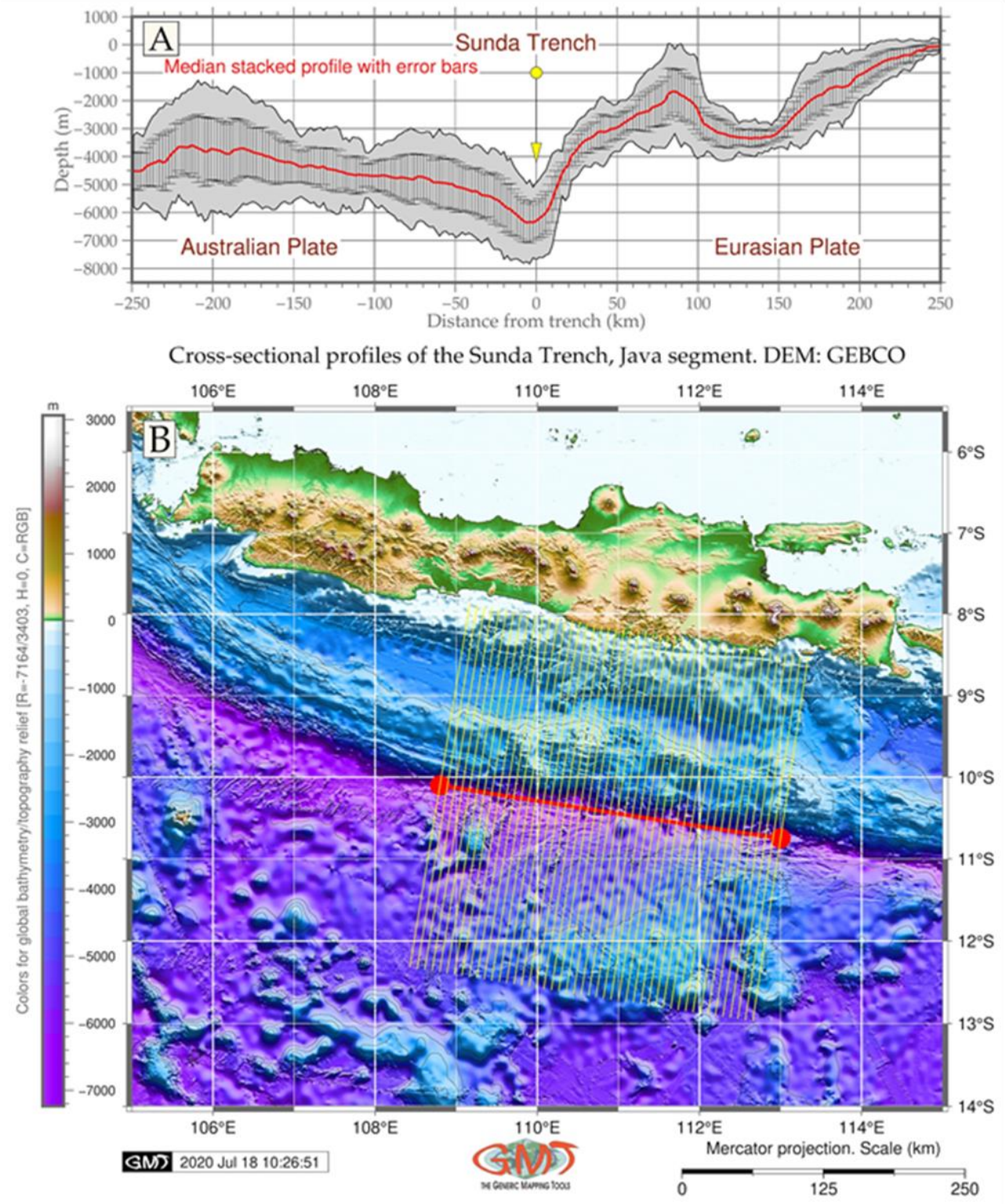

Figure 7 Cross-section profiles of the Sunda Trench: Java segment 
The analysis of the statistical histograms (Fig. 8) shows variation in the depths frequency as data distributed along the segments of the Sumatra and Java segments of the Sunda Trench. The Sunda Trench has a bell-shaped data distribution in contrast to the Sumatra segment which has a bimodal (two-peaked pattern) data distribution. The Java segment (Fig. 8, above) has a pool of data concentrating in the most repetitive depths in a bin with a range $-2,500$ to $-5,200 \mathrm{~m}$. The most repetitive data (above 700 samples) are recorded for the following bins: $-3,500$ to $-3,750 \mathrm{~m}$ (816 samples), $-3,250$ to $3,500 \mathrm{~m}$ (811 samples), $-4,750$ to $-5,000 \mathrm{~m}$ (791 samples), $-2,750$ to $-3,000 \mathrm{~m}$ (743 samples) and 3,000 to $-3,250 \mathrm{~m}$ (721 samples). In shows that in general, the majority of data are concentrated on the depths at $-2,500$ to $-5,200 \mathrm{~m}$.

The Sumatra segment of the Sunda Trench demonstrates a bimodal pattern of the data distribution. Thus, in contrast with the Java transect, the Sumatra transect has the two peaks corresponding to the two intervals: 1) a classic bell-shaped peak at the depths $-4,500 m$ to $-5,500 m$ with values above 600 samples in each bin; 2 ) a distinct shelf area with a peak from 0 to $-1,750 \mathrm{~m}$. The data at the middle depths (between $-1,750$ to $-4,500 \mathrm{~m}$ ) have a frequency below 300 observation points. The most frequent bathymetric data for the Sumatra segment of the trench correspond to the bin of $-4,750 \mathrm{~m}$ to $5,000 \mathrm{~m}$ (2,151 samples). Comparing to the Sumatra segment, the Java segment is in general deeper. For instance, if comparing the depths below $-6,000 \mathrm{~m}$, there are only 138 samples for the Sumatra segment while 547 samples for Java segment. Similarly, the middle -valued depths (those between $-2,000$ to $4,000 \mathrm{~m}$ ) have clearly less samples for the Sumatra segment than for the Java segment (compare both plots in Fig. 8). In context of regional topographic variations, the comparison of the histograms points at the difference in depth distribution for the Sumatra and Java segment of the Sunda Trench: a bimodal character of data distribution for a Sumatra segment Trench and a single-peaked data distribution for a Java segment. Similarly, it shows the difference in depths for the both segments: the southern Java segment is deeper comparing to the Sumatra segment, and the geomorphology of the Su- matra segment has a clear asymmetric view comparing to the more $\mathrm{V}$-shaped Java segment.

\section{Discussion}

The power of GMT-based cartographic visualization, demonstrated in this paper, is primarily relied upon for geospatial analysis, introducing variations in two distinct segments of the Sunda Trench with respect to their local geologic and geophysical settings which explain the terrain segmentation and different slope steepness in two parts of the trench. The paper furthermore discusses the geomorphology of the Sunda Trench, an oceanic trench located in eastern Indian Ocean along the Sumatra and Java Islands of the Indonesian archipelago. The thematic maps and geomorphological modelling were plotted using Generic Mapping Tools (GMT).

The materials include high-resolution data on topography, geology and geophysics: GEBCO 15 arc-minute resolution grid, EGM2008 2.5 minute Earth Gravitation Model of 2008, GlobSed global 5arc-minute total sediment thickness and vector geological datasets. In addition to the GEBCO-based bathymetric data, geological, topographic and geophysical maps, the results include enlarged transects for the Java and Sumatra segments, their slope gradients and cross-section profiles, derived from the bathymetric GEBCO dataset.

The presented histograms show variation in depths along the segments of the Sumatra and Java. The Java segment has a bell-shaped data distribution in contrast to the Sumatra with bimodal pattern. The Java segment has the most repetitive depths at $-2,500$ to $-5,200 \mathrm{~m}$. The Sumatra transect has two peaks: 1) a classic bell-shaped peak at depths $-4,500 m$ to $-5,500 m ; 2$ ) shelf area with a peak from 0 to $-1,750 \mathrm{~m}$. The data at middle depths $(-1,750$ to $-4,500 \mathrm{~m})$ have a frequency $<300$ samples. The most frequent bathymetry for the Sumatra segment corresponds to the $-4,750 \mathrm{~m}$ to $-5,000 \mathrm{~m}$ $(2,151$ samples). Comparing to the Sumatra segment, the Java segment is deeper. For the depths >$6,000 \mathrm{~m}$, there are only 138 samples for the Sumatra while 547 samples for Java. Furthermore, Java segment has more symmetrical geometric shape while Sumatra segment is asymmetric, one-sided. The Sumatra segment has a steepness of $57.86^{\circ}$ on its 
eastern side (facing Sumatra Island) and a contrasting $14.58^{\circ}$ on the western part. The Java segment has a steepness of $64.34^{\circ}$ on its northern side (facing Java Island) and $24.95^{\circ}$ on the southern part (facing Indian Ocean). The paper contributes to the studies of the submarine geomorphology in Indonesia.

The basin of the Indian Ocean, formed as a result of the long-term evolution is characterized by the presence of the ocean trenches (e.g. Makran Trench, Sunda Trench). As shown in the Fig. 3, the region has a relatively thick sediment deposits (exceed of 1,000 m), extended areas of continental rise and presence of submarine fans. Although the area of the Sunda Trench is relatively small within the Indian Ocean, it plays a significant role in the geomorphology of its basin (besides other landforms, such as seamounts, plateau of mid-oceanic ridges), serves as a sediment trap and a habitat for the deep-sea fauna, and a unique geomorphic landform.

Sunda Trench: Sumatra and Java segments: histograms on depths
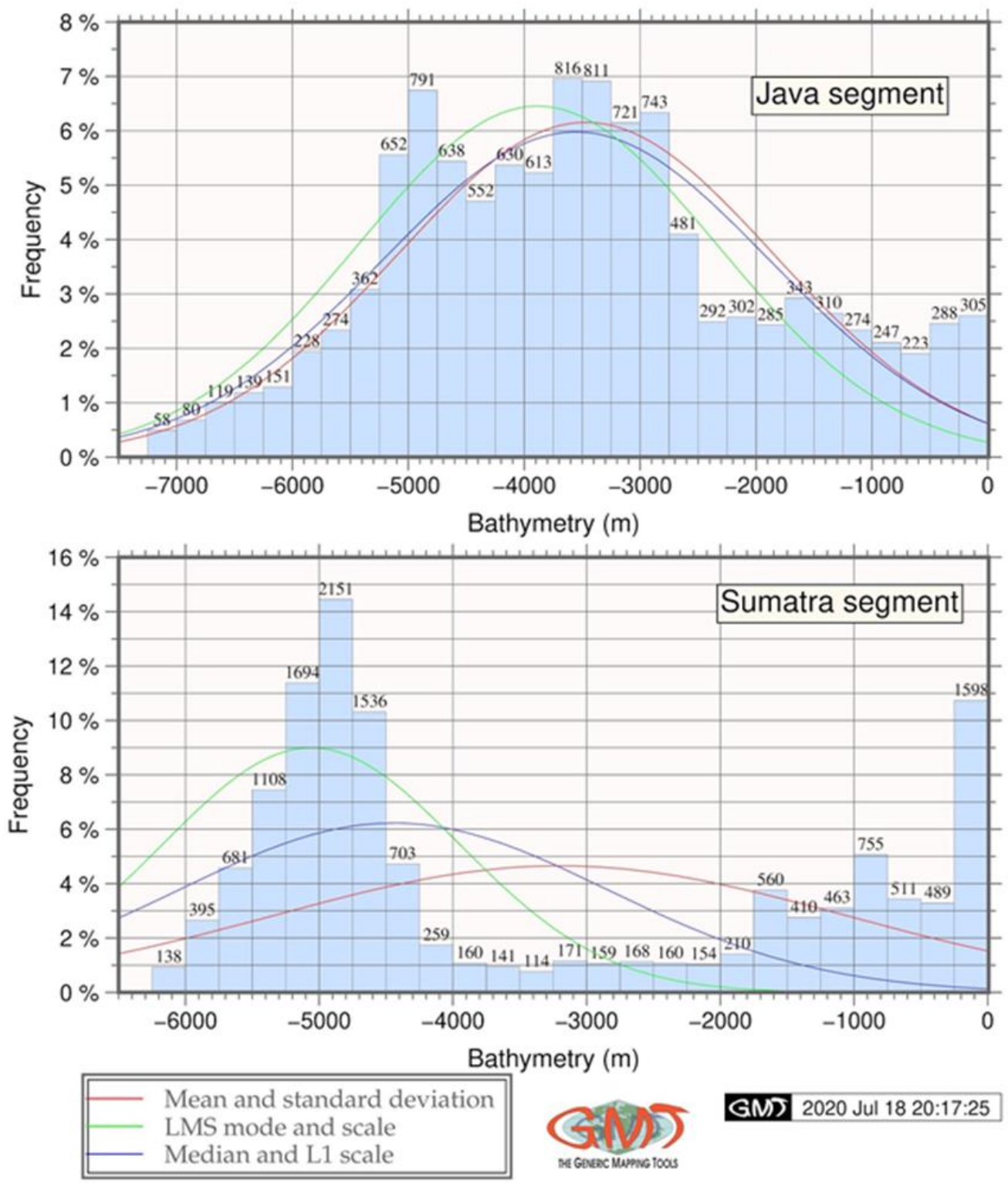

Figure 8 Statistical histograms of the of the Sunda Trench 
The presented GMT techniques for mapping, cross-section digitizing and spatial modelling are an excellent alternative to classical GIS cartographic methods. In particular, scripting iterative methods enable to produce machine-plotted maps with higher precision compared to that achieved with hand-made methods of manual drawing in GIS. A drawback of a console-based cartographic scripting might be its high learning curve: a GMT does not have a standard GUI such as in ArcGIS (Klaučo et al., 2013a, 2013b) but only a console. However, in case of processing of the large volumes of spatial multisource data and a need of digitizing the cross-section segments for bathymetric and geomorphological mapping, scripting techniques of GMT represents an excellent solution to reduce the efforts during cartographic routine and to increase the precision of such unreachable areas as the deep-sea trenches.

This paper reviews the new approach of GMT for automated processing of the high-resolution spatial data and geomorphological modelling approaches for plotting cross-section profiles. Although the geomorphological profiles could be done in other GIS software (QGIS, ArcMap etc.), the cartographical layout differs comparing with those approaches, because the GMT-based graphics is made using the machine approach and hence, the cartographic representation of the plots is presented in more details and accuracy comparing to the traditional hand-made digitizing. Through automatization, the GMT permit geomorphologists to go far beyond traditional mapping using GIS software, because it permits a significant degree of machine-learning approaches, a quantitative characterization of the morphology of the submarine landforms and the integration of the thematic datasets (geophysics, geology, sedimentation) for a deeper analysis of the seafloor geomorphology.

\section{Conclusion}

The paper has given an overview of the presented models of the two segments of the Sunda Trench which contributes to the increase of geomorphological knowledge of this specific region of the Indian Ocean, with emphasis on the Java and Sumatra segments, spatial distinct and differing from each other. The presented GMT methodology has extended the cartographic application of the scripting methods for geomorphological modelling by including code snippets, and also inserted the examples of the code with a GMT syntax. The interaction of the submarine geomorphology with other settings in the study area (geology, sediments, geophysics) results in their impacts on the actual geomorphological landforms in the submarine part of the Indonesian archipelago and explains slope variations in the northern and southern segments of the trench. The article also discussed in general details the regional settings of the study area that include effects of seismicity and geophysical instability which also affect the landforms in various parts of the trench.

The results from the geomorphological models of the two segments regarding the slope steepness and bathymetric variability agree with assumption that the geologic settings and topography is largely reflected in the geomorphological form of the trench. Apart from the fact that that Java segment has a more symmetrical shape form, while the Sumatra segment has an asymmetric one-sided shape, it was pointed out that their steepness vary accordingly. The effectiveness of the GMT has also been demonstrated: comparing to the GMT, usual traditional GIS software is not effective for modelling of the GEBCO grid due to the large dataset of GEBCO $(11,72 \mathrm{~Gb}$ for the GEBCO_2019.nc in a NetCDF format), while the GMT enables to effectively subset the necessary region and process the data subset effectively, precisely and timely. In view of this, the GMT presented an effective cartographic solution for processing big data in geomorphological modelling.

The submarine geomorphology of the oceanic trenches is formed as a result of the complex interactions between the processes of the tectonic plate subduction, geologic setting of the region and geodynamic. As a structural part of the ocean seafloor topography, the evolution of the oceanic trench reflects these changes, which are mirrored in its actual shape (Lemenkova, 2019d). This suggests that submarine topography has mainly a dynamic character, being strongly influenced by both the previous geologic evolution and current external geo- 
physical and geodynamic factors. The complexity of the natural phenomena and the connectivity and responses between various geological, geomorphic and climate factors are discussed previously (Moore et al., 1976; Kuhn et al., 2006; Widiyantoro et al., 2011).

The increased availability of high resolution grids (GEBCO, EGM2008, SRTM) enables to better distinguish the genetic origin of the seafloor landforms. Using datasets with a globe coverage allows better understand the context of the submarine geomorphological systems of the oceanic trenches in context of their regional geophysical setting, geological development and tectonic history. Needless to say that this progress has been facilitated by a rapid development of the machine learning techniques, data science approaches and efforts in open data repositories by SIO and GEBCO. Last but not least, the progress in the computer hardware and memory enables to process big datasets for the geomorphological mapping (e.g. original GEBCO grid, $11,72 \mathrm{~Gb})$.

The geomorphological mapping strongly depends on the input data quality and resolution. Thus, the bathymetric data can vary in terms of precision e.g. GEBCO 15 arc-second data acquired for visualizing seafloor versus regional-scale compilations from ETOPO1, ETOPO2 or ETOPO5 with 1, 2 and 5-minute resolution, respectively. Therefore, the quality of the initial bathymetric grids facilitates the delineation of the geomorphological features in the output maps. In particular, it is true for the semiautomated techniques, as demonstrated by the GMT cross-sectional profiling. Higher-resolution topographic raster grids increase the overall quality of the output geomorphological slope profiling. In contrary, poorer resolution cannot ensure the appropriate results in slope modelling. As mentioned before, this research is based on the 15 arc-second resolution topographic GEBCO grid, which ensured the quality and the precision of the results.

The automated data processing approaches of GMT enables time-efficient, precise and accurate cartographic visualization and geomorphological modelling using large data volumes, which now replaces the error-prone traditional, biased, manual methods of data interpretation. Besides, certain
GMT modules ('pshistogram') provide statistical methods of data processing and descriptive statistical analysis. Automated methods of the machine learning provided by GMT, as demonstrated in this paper, significantly reduce mapping subjectivity, labour time and mistakes. Human interpretation can be reduced to the interpretation of the layout outputs and writing the script. The geomorphological interpretation of the landforms can also be used for the additional description of natural complexity and analysis of the correlation with information of the geological and tectonic evolution and geophysical settings of the deep-sea trench. This paper contributed to the regional studies of the Indian Ocean, the geomorphology of the oceanic seafloor and methodological developing of the cartographic approaches in geomorphological mapping.

\section{Acknowledgements}

The author would like to express the gratitude to the two anonymous reviewers for their helpful suggestions, constructive and useful remarks that helped improve a previous version of the typescript. This research has been supported and implemented in the framework of the Project No. 0144-20190011, Schmidt Institute of Physics of the Earth, the Russian Academy of Sciences.

\section{References}

Abercrombie RE, Antolik M, Felzer K, Ekström G. 2001. The 1994 Java tsunami earthquake: Slip over a subducting seamount. Journal of Geophysical Research, 106: 6595-6607. https://doi.org/10.1029/2000JB900403

Abidin $H Z$, Andreas $H$, Gamal $M$, Wirakusumah $A D$, Darmawan D, Deguchi T, Maruyama Y, 2008. Land subsidence characteristics of the Bandung Basin, Indonesia, as estimated from GPS and InSAR. Journal of Applied Geodesy, 2(3): 167-177. https://doi.org/10.1515/JAG.2008.019

Advokaat EL, Marshall NT, Li S, Spakman W, Krijgsman W, van Hinsbergen DJJ. 2018. Cenozoic rotation history of Borneo and Sundaland, SE Asia revealed by paleomagnetism, seismic tomography, and kinematic reconstruction. Tectonics, 37(8): 2486-2512. https://doi.org/10.1029/2018TC005010

Advokaat EL, Bongers MLM, Rudyawan A, BouDagherFadel MK, Langereis CG, Van Hinsbergen DJJ. 2018. Early Cretaceous origin of the Woyla Arc (Sumatra, 
Indonesia) on the Australian plate. Earth and Planetary Science Letters, 498: 348-361.

https://doi.org/10.1016/j.epsl.2018.07.001

Ammon CJ, Kanamori H, Lay T, Velasco AA. 2006. The 17 July 2006 Java tsunami earthquake. Geophysical Research Letters, 33: L24308.

https://doi.org/10.1029/2006GL028005

Anikouchine WA, Ling H. 1967. Evidence for turbidite accumulation in trenches in the Indo-Pacific region. Marine Geology, 5: 141-154.

Barber AJ. 1981. Structural interpretation of the island of Timor, eastern Indonesia. In: E.J. Barber and S. Wiryosujono Eds. The geology and tectonics of eastern Indonesia. GRDC Special Publications, 2: 183198.

Barber AJ, Crow MJ. 2009. Structure of Sumatra and its implications for the tectonic assembly of Southeast Asia and the destruction of Paleotethys. Island ArC, 18(1): $\quad 3-20 . \quad$ https://doi.org/10.1111/j.14401738.2008.00631.x

Bellier O., Sébrier $M$, Pramumijoyo $S$, Beaudouin $T$, Harjono H, Bahar I, Forni O. 1997. Paleoseimicity and seismic hazard along the ornat Sumatran Fault (Indonesia). Journal of Geodynamics, 24: 169-183. https://doi.org/10.1016/S0264-3707(96)00051-8

Van Bemmelen RW. 1970. The Geology of Indonesia. $2^{\text {nd }}$ edition, Martinus Nijhoff, The Hague.

Bishop MP, James LA, Shroder Jr JF, Walsh SJ. 2012. Geospatial Technologies and Digital Geomorphological Mapping: Concepts, Issues and Research. Geomorphology, 137: 5-26. https://doi.org/10.1016/j.geomorph.2011.06.027

Caméron NR, Clarke MCG, Aldiss DT, Aspden JA, Djunuddin A. 1980. The geological evolution of northern Sumatra. Proceedings Indonesian Petrology Association, $9^{\text {th }}$ Annual Convention, 149-187.

Cardwell RK, Isacks BL. 1978. Geometry of the subducted lithosphere beneath the Banda Sea in eastern Indonesia from seismicity and fault plane solutions. Journal of Geophysical Research, 83(B6): 2825-2838. https://doi.org/10.1029/JB083iB06p02825

Chlieh M, Avouac JP, Sieh K, Natawidjaja DH, Galetzka J, 2008. Heterogeneous coupling of the Sumatran megathrust constrained by geodetic and paleogeodetic measurements. Journal of Geophysical Research, 113: B05305. https://doi.org/10.1029/2007JB004981

Curray JR, Emmel FJ, Moore DG, Raitt RW. 1982. Structure, Tectonics, and Geological History of the Northeastern Indian Ocean. In: Nairn AEM, Stehli FG. (eds) The Ocean Basins and Margins. Springer, Boston, MA.

Curray JR, Shor GG Jr, Raitt RW, Henry M. 1977. Seismic refraction and reflection studies of crustal structure of the Eastern Sunda and Western Banda Arcs. Journal of Geophysical Research, 82: 2479-2489.

https://doi.org/10.1029/JB082i017p02479

Daly MC, Cooper MA, Wilson I, Smith DG, Hooper BGD. 1991. Cenozoic plate tectonics and basin evolution in Indonesia. Marine and Petroleum Geology, 8(1): 2-21. https://doi.org/10.1016/0264-8172(91)90041-X

Dokht, RMH, Gu YJ, Sacchi MD. 2018. Migration imaging of the Java subduction zones. Journal of Geophysical Research: Solid Earth, 123(2): 1540-1558. https://doi.org/10.1002/2017JB014524

Dziewonski AM, Chou TA, Woodhouse JH. 1981. Determination of earthquake source parameters from waveform data for studies of global and regional seismicity. Journal of Geophysical Research, 86(B4): 2825-2852. https://doi.org/10.1029/JB086iB04p02825

Ekström G, Nettles M, Dziewoński AM. 2012. The global CMT project 2004-2010: Centroid-moment tensors for 13,017 earthquakes. Physics of the Earth and Planetary Interiors, 200: 1-9.

https://doi.org/10.1016/j.pepi.2012.04.002

Fuji Y, Satake K, 2006. Source of the July 2006 West Java tsunami estimated from tide gauge records. Geophysical Research Letters, 33: L24317. https://doi.org/10.1029/2006GL028049

Gauger S, Kuhn G, Gohl K, Feigl T, Lemenkova P, Hillenbrand C. 2007. Swath-bathymetric mapping. Reports on Polar and Marine Research, 557: 38-45. https://doi.org/10.6084/m9.figshare.7439231

GEBCO Compilation Group 2020. GEBCO 2020 Grid. https://doi.org/10.5285/a29c5465-b138-234d-e0536c86abc040b9

GDAL/OGR contributors 2020. GDAL/OGR Geospatial Data Abstraction software Library. Open Source Geospatial Foundation. https://gdal.org [online accessed: 17 July 2020].

Grevemeyer I, Tiwari VM. 2006. Overriding Plate Controls and Spatial Distribution Of Megathrust Earthquakes in the Sunda-Andaman Subduction Zone. Earth and Planetary Science Letters, 251: 199-208. https://doi.org/10.1016/j.epsl.2006.08.021

Gunawan E, Widiyantoro S, Rosalia S, Daryono MR, Meilano I, Supendi P, Ito T, Tabei T, Kimata F, Ohta Y, Ismail N. 2018. Coseismic slip distribution of the 2 july $2013 \mathrm{Mw} 6.1$ aceh, Indonesia, earthquake and its tectonic implications. Bulletin of the Seismological Society of America, 108(4): 1918-1928, https://doi.org/10.1785/0120180035

Gunawan E, Widiyantoro S, Supendi P, Nishimura T. 2020. Identifying the most explainable fault ruptured of the 2018 Palu-Donggala earthquake in Indonesia using coulomb failure stress and geological field report. 
Geodesy and Geodynamics, 11: 252-257. https://doi.org/10.1016/j.geog.2020.04.004

Hamilton W. 1977. Subduction in the Indonesian Region. In Talwani, M. and Pittman, W. C. (eds.), Island Arcs, Deep-Sea Trenches and Back-Arc Basins, American Geophysical Union Maurice Ewing Series, 1: 15-31.

Hamilton W. 1978. Tectonic map of the Indonesian region. U. S. Geological Survey Map I-875-D.

Hamilton W. 1979. Tectonics of the Indonesian Region. U.S. Geological Survey Professional Paper, 1078: 345. https://doi.org/10.3133/pp1078

Harjono $H$, Diament $M$, Dubois J, Larue $M, 1991$. Seismicity of the Sunda strait: evidence for crustal extension and volcanological implications. Tectonics, 10: 17-30. https://doi.org/10.1029/90TC00285

IHO-IOC. 2012. GEBCO Gazetteer of Undersea Feature Names.

Jena R, Pradhan B, Beydoun G, Alamri AM, Ardiansyah, Nizamuddin, Sofyan H. 2020a. Earthquake hazard and risk assessment using machine learning approaches at Palu, Indonesia. Science of The Total Environment, 749: 141582.

https://doi.org/10.1016/j.scitotenv.2020.141582

Jena R, Pradhan B, Beydoun G, Nizamuddin, Ardiansyah, Sofyan H, Affan M. 2020b. Integrated model for earthquake risk assessment using neural network and analytic hierarchy process: Aceh province, Indonesia. Geoscience Frontiers, 11: 613-634. https://doi.org/10.1016/j.gsf.2019.07.006

Karig DE, Moore GF, Curray JR, Lawrence MB. 1980. Morphology and shallow structure of the trench slope off Nias Island, Sunda Arc. In: Hayes DE. (ed.). The Tectonic and Geologic Evolution of Southeast Asian Seas and Islands, Geophysical Monograph Series Washington, 23: 179-208. ISBN: 978-1-118-66379-0, $326 \mathrm{pp}$.

Karig DE, Suparka S, Moore GF, Hehanussa PE. 1979. Structure and Cenozoic Evolution of the Sunda Arc in the Central Sumatra Region'. In Watkins, J. S., Montadert, L., and Dickerson, P. W. (eds.), Geological and Geophysical Investigations of Continental Slopes and Rises, American Association of Petroleum Geologists, Memoir, 29: 223-237.

Katili JA. 1972. Plate Tectonics of Indonesia with Special Reference to the Sundaland Area. Proceedings of the 1st Annual Convention Indonesian Petroleum Association: $\quad$ 57-61. https://doi.org/10.29118/IPA.1921.57.61

Katili JA. 1973. Geochronology of west Indonesia and its implication on plate tectonics. Tectonophysics, 19: 195-212.https://doi.org/10.1016/0040-1951(73)90019$\mathrm{X}$
Kieckhefer RM, Shor GGJr, Curray JR, Sugiarta W, Hehuwat F. 1980. Seismic Refraction Studies of the Sunda Trench and Forearc Basin. Journal of Geophysical Research, 85: 863-889. https://doi.org/10.1029/JB085iB02p00863

Klaučo M, Gregorová B, Stankov U, Marković V, Lemenkova P. 2013a. Determination of ecological significance based on geostatistical assessment: a case study from the Slovak Natura 2000 protected area. Central European Journal of Geosciences, 5(1): 28-42. https://doi.org/10.2478/s13533-012-0120-0

Klaučo M, Gregorová B, Stankov U, Marković V, Lemenkova P. 2013b. Interpretation of Landscape Values, Typology and Quality Using Methods of Spatial Metrics for Ecological Planning. 54 th International Conference Environmental \& Climate Technologies. Riga, Latvia.

https://doi.org/10.13140/RG.2.2.23026.96963

Klaučo M, Gregorová B, Stankov U, Marković V, Lemenkova P. 2014. Landscape metrics as indicator for ecological significance: assessment of Sitno Natura 2000 sites, Slovakia. Ecology and Environmental Protection, 85-90. https://doi.org/10.6084/m9.figshare. 7434200

Klaučo M, Gregorová B, Stankov U, Marković V, Lemenkova P. 2017. Land planning as a support for sustainable development based on tourism: A case study of Slovak Rural Region. Environmental Engineering and Management Journa/ 2(16): 449-458. https://doi.org/10.30638/eemj.2017.045

Klinger T, Heipke C, Ott N, Schenke HW, Ziems M. 2012. Automated Extraction of the Antarctic Coastline Using Snakes. A special joint symposium of ISPRS Technical Commission IV \& AutoCarto in conjunction with ASPRS/CaGIS 2010 Fall Specialty Conference November 15-19, 2010 Orlando, Florida.

Kopp H. 2011. The Java convergent margin: structure, seismogenesis and subduction processes, Geological Society, London, Special Publications 355: 1, 111-137. https://doi.org/10.1144/SP355.6

Kuhn G, Hass C, Kober M, Petitat M, Feigl T, Hillenbrand $C D$, Kruger S, Forwick M, Gauger S, Lemenkova P. 2006. The response of quaternary climatic cycles in the South-East Pacific: development of the opal belt and dynamics behavior of the West Antarctic ice sheet. In: Gohl K. (ed.). Expeditions programme 75 ANT XXIII/4. https://doi.org/10.13140/RG.2.2.11468.87687

Lemenkova P. 2020a. Fractal surfaces of synthetical DEM generated by GRASS GIS module r.surf.fractal from ETOPO1 raster grid. Journal of Geodesy and Geoinformation, 7(1):86-102. https://doi.org/10.9733/JGG.2020R0006.E 
Lemenkova P. 2020b. NOAA Marine Geophysical Data and a GEBCO Grid for the Topographical Analysis of Japanese Archipelago by Means of GRASS GIS and GDAL Library. Geomatics and Environmental Engineering, 14(4), 25-45.

https://doi.org/10.7494/geom.2020.14.4.25

Lemenkova P. 2020c. Variations in the bathymetry and bottom morphology of the Izu-Bonin Trench modelled by GMT. Bulletin of Geography. Physical Geography Series 18(1): 41-60.

https://doi.org/10.2478/bgeo-2020-0004

Lemenkova P. 2020d. GMT Based Comparative Geomorphological Analysis of the Vityaz and Vanuatu Trenches, Fiji Basin. Geodetski List, 74(1): 19-39. https://doi.org/10.6084/m9.figshare.12249773

Lemenkova P. 2019a. Statistical Analysis of the Mariana Trench Geomorphology Using $\mathrm{R}$ Programming Language. Geodesy and Cartography, 45(2): 57-84. https://doi.org/10.3846/gac.2019.3785

Lemenkova P. 2019b. Topographic surface modelling using raster grid datasets by GMT: example of the Kuril-Kamchatka Trench, Pacific Ocean. Reports on Geodesy and Geoinformatics, 108: 9-22. https://doi.org/10.2478/rgg-2019-0008

Lemenkova P. 2019c. GMT Based Comparative Analysis and Geomorphological Mapping of the Kermadec and Tonga Trenches, Southwest Pacific Ocean. Geographia Technica, 14(2): 39-48.

https://doi.org/10.21163/GT_2019.142.04

Lemenkova P. 2019d. Geophysical Modelling of the Middle America Trench using GMT. Annals of Valahia University of Targoviste. Geographical Series, 19(2): 73-94. https://doi.org/10.6084/m9.figshare.12005148

Lemenkova P. 2019e. AWK and GNU Octave Programming Languages Integrated with Generic Mapping Tools for Geomorphological Analysis. GeoScience Engineering, 65(4): 1-22. https://doi.org/10.35180/gse-2019-0020

Lemenkova P. 2019f. Testing Linear Regressions by StatsModel Library of Python for Oceanological Data Interpretation. Aquatic Sciences and Engineering, 34: 51-60. https://doi.org/10.26650/ASE2019547010

Lemenkova P. 2019g. An Empirical Study of R Applications for Data Analysis in Marine Geology. Marine Science and Technology Bulletin, 8(1): 1-9. https://doi.org/10.33714/masteb.486678

Lemenkova P. 2018. R scripting libraries for comparative analysis of the correlation methods to identify factors affecting Mariana Trench formation. Journal of Marine Technology and Environment, 2: 35-42. https://doi.org/10.6084/m9.figshare.7434167

Lemenkova P, Promper C, Glade T. 2012. Economic Assessment of Landslide Risk for the Waidhofen a.d. Ybbs Region, Alpine Foreland, Lower Austria. In:
Eberhardt E, Froese C, Turner AK, Leroueil S. (eds.) Protecting Society through Improved Understanding. $11^{\text {th }}$ International Symposium on Landslides $\&$ the $2^{\text {nd }}$ North American Symposium on Landslides \& Engineered Slopes (NASL), June 2-8, 2012. Banff, Canada, 279-285.

https://doi.org/10.6084/m9.figshare.7434230

Lemenkova P. 2011. Seagrass Mapping and Monitoring Along the Coasts of Crete, Greece. M.Sc. Thesis. Netherlands: University of Twente. 158 p. https://doi.org/10.13140/RG.2.2.16945.22881

Litvin VM. 1987. Morphostructure of the ocean seafloor. Nedra, Leningrad.

Marchetti D, De Santis A, Shen X, Campuzano SA, Perrone L, Piscini A, Di Giovambattista R, Jin S, Ippolito $A$, Cianchini G, Cesaroni C, Sabbagh D, Spogli L, Zhima Z, Huang J. 2020. Possible Lithosphere-AtmosphereIonosphere Coupling effects prior to the 2018 $\mathrm{Mw}=7.5$ Indonesia earthquake from seismic, atmospheric and ionospheric data. Journal of Asian Earth Sciences, 188: 104097.

https://doi.org/10.1016/j.jseaes.2019.104097

Mammerickx J, Fisher RL, Emmel FJ, Smith SM. 1976. Bathymetry of the East and Southeast Asian Seas. Geological Society of America, Map \& Chart Series MC-17.

McDonald JM. 1977. Sediments and Structure of the Nicobar Fan, Northeast Indian Ocean. Unpub. Ph. D. Thesis, U.C.S.D., $148 \mathrm{p}$.

Meservy W, Harris R, Setiadi G, Hapsoro S. 2020. Coastal boulder fields and tsunami hazards of East Java, Indonesia. EGU General Assembly 2020, Online, 4-8 May 2020, EGU2020-22118,

https://doi.org/10.5194/egusphere-egu2020-22118

Moore DG, Curray JR, Emmel FJ. 1976. Large submarine slide (olistostrome) associated with Sunda Arc subduction zone, northeast Indian Ocean. Marine Geology, 21: 211-226. https://doi.org/10.1016/00253227(76)90060-8

Moore GF, Curray JR. 1980. Structure of the Sunda Trench lower slope off Sumatra from multichannel seismic reflection data. Marine Geophysical Research, 4: 319340. https://doi.org/10.1007/BF00369106

Moore GF, Curray JR, Emmel, FJ. 1982. Sedimentation in the Sunda Trench and forearc region. Geological Society, London, Special Publications, 10: 245-258. https://doi.org/10.1144/GSL.SP.1982.010.01.16

Moya L, Muhari A, Adriano B, Koshimura S, Mas E, MarvalPerez LR, Yokoya N. 2020. Detecting urban changes using phase correlation and $\ell 1$-based sparse modelfor early disaster response: A case study of the 2018 Sulawesi Indonesiaearthquake-tsunami. Remote Sensing of Environment, 242: 111743. 
https://doi.org/10.1016/j.rse.2020.111743

Nalbant SS, Steacy S, Sieh K, Natawidjaja D, McCloskey J. 2005. Earthquake risk on the Sunda Trench. Nature, 435: 756-757. https://doi.org/10.1038/nature435756a

NASA. (2018). Satellite-derived map of ground deformation from earthquake beneath Lombok, Indonesia. https://disasters.nasa.gov/lombokindonesia-earthquake-2018/satellite-derived-mapground-deformation-earthquake-beneath-lombok Accessed on November 19, 2020.

Nurwihastuti DW, Sartohadi J, Mardiatno D, Nehren U, Restu. 2014. Understanding of Earthquake Damage Pattern through Geomorphological Approach: A Case Study of 2006 Earthquake in Bantul, Yogyakarta, Indonesia. World Journal of Engineering and Technology, 02(3B): 61-70.

https://doi.org/10.4236/wjet.2014.23B010

Pavlis NK, Holmes SA, Kenyon SC, Factor JK. 2012. The development and evaluation of the Earth Gravitational Model 2008 (EGM2008). Journal of Geophysical Research, 117: B04406, https://doi.org/10.1029/2011JB008916

Pollitz FF, Banerjee $P$, Bürgmann $R$, Hashimoto $M$, Choosakul N. 2006. Stress changes along the Sunda Trench following the 26 December 2004 SumatraAndaman and 28 March 2005 Nias earthquakes. Geophysical Research Letters, 33: L06309. https://doi.org/10.1029/2005GL024558

Pubellier M, Ego F, Chamot-Rooke N, Rangin C. 2003. The building of pericratonic mountain ranges: structural and kinematic constraints applied to GIS-based reconstructions of SE Asia. Bulletin de la Société Géologique France, 174(6): 561-584. https://doi.org/10.2113/174.6.561

Rahardjo W, Sukandarrumidi, Rosidi HMD. 1995. Geological Map of the Yogyakarta Sheet, Jawa, Scale 1:100.000. Geological Research and Development Centre, Bandung.

Sandwell DT, Müller RD, Smith WHF, Garcia E, Francis R. 2014. New global marine gravity model from CryoSat2 and Jason-1 reveals buried tectonic structure. Science, 346(6205): 65-67.

https://doi.org/10.1126/science.1258213

Schenke HW, Lemenkova P. 2008. Zur Frage der Meeresboden-Kartographie: Die Nutzung von AutoTrace Digitizer für die Vektorisierung der Bathymetrischen Daten in der Petschora-See. Hydrographische Nachrichten, 81: 16-21. https://doi.org/10.6084/m9.figshare.7435538

Setijadji LD, Watanabe K, Barianto DH, Rahardjo W, Sudarno I, Susilo A, Itaya T. 2008. Searching for the Active Fault of the Yogyakarta Earthquake of 2006 Using Data Integration on Aftershocks, Cenozoic Geo-
History, and Tectonic Geomorphology. In: Karnawati D, Pramumijoyo S, Anderson R, Husein S. (eds.) The Yogyakarta Earthquake of May 27, 2006. Star Publisher, Los Angeles.

Smith WHF. 1993. On the accuracy of digital bathymetric data. Journal of Geophysical Research, 98(B6): 95919603. https://doi.org/10.1029/93JB00716

Smith WHF, Sandwell DT. 1995. Marine gravity field from declassified Geosat and ERS-1 altimetry. EOS Transactions of the American Geophysical Union, 76, Fall Mtng Suppl: F156.

Smyth H, Hall R, Hamilton J, Kinny P. 2005. East Java: Cenozoic Basins, Volcanoes and Ancient Basement. Proceedings, Indonesian Petroleum Association, Thirtieth Annual Convention \& Exhibition, August 2005.

Socquet A, Hollingsworth J, Pathier E, Bouchon M. 2019. Evidence of supershear during the 2018 magnitude 7.5 Palu earthquake from space geodesy. Nature Geoscience, 12(3): 192-199.

https://doi.org/10.1038/s41561-018-0296-0

Song R, Hattori K, Zhang X, Sanaka S. 2020. Seismicionospheric effects prior to four earthquakes in Indonesia detected by the China seismoelectromagnetic satellite. Journal of Atmospheric and Solar-Terrestrial Physics, 205: 105291. https://doi.org/10.1016/j.jastp.2020.105291

Sørensen M, Atakan K. 2008. Continued earthquake hazard in Northern Sumatra: Potential effects of a future earthquake. Eos Transactions of the American Geophysical Union, 89(14): 133-134. https://doi.org/10.1029/2008EO140001

Stagpoole V, Schenke HW, Ohara Y. 2016. A name directory for the ocean floor. Eos, 97. https://doi.org/10.1029/2016EO063177

Straume EO, Gaina C, Medvedev S, Hochmuth K, Gohl K, Whittaker JM, Abdul Fattah R, Doornenbal JC, Hopper JR. 2019. GlobSed: Updated total sediment thickness in the world's oceans. Geochemistry, Geophysics, Geosystems, 20(4): 1756-1772. https://doi.org/10.1029/2018GC008115

Suetova IA, Ushakova LA, Lemenkova P. 2005. Geoinformation mapping of the Barents and Pechora Seas. Geography and Natural Resources, 4: 138-142. https://doi.org/10.6084/m9.figshare.7435535

Tozer B, Sandwell DT, Smith WHF, Olson C, Beale JR, Wessel P. 2019. Global bathymetry and topography at 15 arc sec: SRTM15+. Earth and Space Science, 6(10): 1847-1864. https://doi.org/10.1029/2019EA000658

Tregoning $P$, Brunner FK, Bock $Y$, Puntodewo SSO, McCaffrey R, Genrich JF, Calais E, Rais J, Subarya C. 1994. First geodetic measurement of convergence 
across the Sunda Trench. Geophysical Research Letters, 21(19): 2135-2138. https://doi.org/10.1029/94GL01856

Van Zuidam RA. 1985. Aerial Photo-Interpretation Terrain Analysis and Geomorphology Mapping. Smits Publishers, The Hague, $442 \mathrm{p}$.

Verstappen HT. 2000. Outline of the Geomorphology of Indonesia: A Case Study on Tropical Geomorphology of a Techtogene Region. ITC Publication 79, Enschede.

Yulianto E, Utari P, Satyawan IA. 2020. Communication technology support in disaster-prone areas: Case study of earthquake, tsunami and liquefaction in Palu, Indonesia. International Journal of Disaster Risk Reduction, 45: 101457. https://doi.org/10.1016/j.ijdrr.2019.101457

Weatherall P, Marks KM, Jakobsson M, Schmitt T, Tani S, Arndt JE, Rovere M, Chayes D, Ferrini V, Wigley R. 2015. A new digital bathymetric model of the world's oceans. Earth and Space Science, 2(8): 331-345 https://doi.org/10.1002/2015EA000107
Wessel P, Watts AB. 1988. On the accuracy of marine gravity measurements. Journal of Geophysical Research, 93: 393-413.

https://doi.org/10.1029/JB093iB01p00393

Wessel P, Smith WHF. 1991. Free software helps map and display data. Eos Transactions of the American Geophysical Union, 72(41): 441. https://doi.org/10.1029/90EO00319

Wessel P, Smith WHF. 1996. A Global Self-consistent, Hierarchical, High-resolution Shoreline Database. Journal of Geophysical Research, 101: 8741-8743. https://doi.org/10.1029/96JB00104

Wessel P, Smith WHF, Scharroo R, Luis JF, Wobbe F. 2013. Generic mapping tools: Improved version released. Eos Transactions of the American Geophysical Union, 94(45): 409-410. https://doi.org/10.1002/2013EO450001

Widiyantoro S, Pesicek JD, Thurber CH. 2011. Subducting slab structure below the eastern Sunda arc inferred from non-linear seismic tomographic imaging. Geological Society, London, Special Publications, 355(1): 139-155. https://doi.org/10.1144/SP355.7 